\title{
Studerendes informationspraksis omkring den akademiske opgave
}

\author{
Af Maria Viftrup Schneider og Susanne Thrige
}

\begin{abstract}
Med udgangspunkt i Annemaree Lloyds informationspraksis-begreb analyserer artiklen studerendes informationspraksis med fokus på brugen af tekstuelle, sociale og kropslige informationskilder. Analysen baserer sig på en interviewundersøgelse af 8 studerendes oplevelse af akademisk opgaveskrivning og informationssøgning på to bacheloruddannelser. Undersøgelsen belyser dels studerendes brug af de tre forskellige informationskilder, og dels hvordan denne brug synes at vare påvirket af deres opfattelse af den uddannelsesmoessige kontekst (alignment), samt deres vurdering af den 'tilstrcekkelige' indsats (satisficing).
\end{abstract}

\section{Indledning}

Nyere forskning stiller spørgsmålstegn ved universelle definitioner af begrebet informationskompetence, og peger på det problematiske $\mathrm{i}$ at betragte fænomenet som en almen færdighed (Tuominen, Savolainen \& Talja, 2005; Sundin, Limberg \& Lundh, 2008; Lloyd 2006). Fra slutningen af 1990'erne begynder forskningen at lægge vægt på kontekstens betydning for forståelsen af informationskompetence (Bruce, 1997; Bruce, 1999; Bawden \& Robinson, 2002). Informationskompetence beskrives her som værende noget forskelligt, afhængigt af den kontekst, hvori kompetencen udfolder sig. Således er det ikke den samme informationskompetence der praktiseres $i$ en uddannelses-, en arbejdslivs- eller en hverdagslivskontekst.

Uddannelsessektoren er den arena, hvor informationskompetence er blevet diskuteret mest. Her er en mangeårig tradition for undervisning $\mathrm{i}$ informationssøgning, og for formulering af læringsmål, der er influeret af formulerede standarder for informationskompetence. I uddannelsessektoren ses informationskompetence som "akademisk ladet" - et videnskabeligt ideal (Pilerot, 2009, s. 109), hvor kundskab anses som noget der kan søges.

I uddannelsesbibliotekerne har vi traditionelt fokus på at lære vores studerende at tilgå og håndtere tekstuel information. I denne artikel, som baserer sig på vores masterprojekt "Informationspraksis omkring den akademiske opgave" (Schneider \& Thrige, 
2011), har vi fokus på, hvilke andre typer af information studerende anvender i deres akademiske praksis, og hvilke faktorer der påvirker deres brug af informationskilder.

Studerendes efterspørgsel af information om rammerne for opgaveskrivning, fremgår af rapporten "Finding context" (Head \& Eisenberg, 2009). Denne konkluderer bl.a., at den "situationelle kontekst", defineret som information om forventninger og krav fra uddannelsens side, er særdeles væsentlig for de studerende. De studerendes evne til at aflæse den kontekst, og dermed den praksis de er situeret i, er afgørende for deres præstationer.

Artiklen indledes med redegørelse for de teoretiske begreber som vi anvender i vores analyse: Informationspraksis, "Alignment" og "Satisfycing". Herefter redegøres for vores undersøgelsesmateriale og metode. Vores resultater vedrørende informationspraksis, præsenteres ud fra den beskrevne brug af henholdsvis tekstuelle, sociale og kropslige informationskilder i arbejdet med den akademiske opgave og informationssøgning. Det er især brugen af tekstuelle og sociale informationskilder, som inddrages, hvorimod det har vist sig vanskeligt at belyse de kropslige informationskilder. Dette kan bl.a. relateres til valg af metode. Efter ovenstående præsentation redegøres der ved hjælp af begrebet "alignment", for hvilken betydning de studerendes oplevelse af de kontekstuelle faktorer har for deres informationspraksis. Ligeledes redegøres for betydningen af "satisfycing"adfærd for deres informationspraksis. Herefter diskuteres metodevalget kort. Artiklen afsluttes med en konklusion.

I det følgende vil vi præsentere begrebet informationspraksis og Annemaree Lloyd's ${ }^{1}$ forståelse af begrebet.

\section{Informationspraksis}

Begrebet "informationspraksis" vinder frem i starten af det 21. århundrede, og kan anses som et alternativ til det dominerende psykologiske begreb "informationsadfærd" (Savolainen, 2007). Begge begreber beskriver måder hvorpå mennesker håndterer information, men begrebet informationspraksis repræsenterer en mere sociologisk og kontekstorienteret linie i forskningen. Med brugen af praksisbegrebet skifter fokus fra adfærd, handlinger, motiver og færdigheder hos individer, til opmærksomhed på individer som medlemmer af forskellige fællesskaber, hvor deres aktiviteter konstitueres af konteksten (ibid, s. 120). Informationspraksis giver sociale og kulturelle faktorer den centrale rolle, og har fokus på informationsdelingsprocesser.

Kontekstbegrebet knytter sig til den lærendes fysiske lokation, til den situation den lærende befinder sig i, til forholdet til andre studerende, til læringsmål- og strategier, samt til problemløsnings- og samarbejdsformer.

Praksisteori søger at redegøre for de praksisser som mennesker indgår i, og har opmærksomhed på vigtige aspekter af menneskelig aktivitet, som ellers er skjult eller "tavs". Hermed menes, at information kommer til udtryk gennem den menneskelige gøren og laden, og ikke bliver eksplicit udtrykt (Lave \& Wenger, 2007). Således søger praksisteori at forklare det sociale liv, omkring, hvordan man gør ting og hvorfor. Praksis har betydning for menneskers forståelse og fortolkning af regler og normer, og praksis fremmer udviklingen af delte forståelser og delte færdigheder i det sociale fællesskab (Rouse, 2007, s. 645).

Med begrebet Informationspraksis forsøger man at udvide og forny forståelsen af informationskompetence fra noget individuelt til en social praksis, hvor den måde, hvorpå der indhentes information, i høj grad er influeret af den praksis (eller kontekst) som indhentningen foregår i.

Lloyd tager begrebet "informationspraksis" i brug i 2007, i forbindelse med hendes studie af brandmænds oplevelse og brug af information i deres proces med at blive "professionelle udøvere" af deres fag (Lloyd, 2007a). Hun har hovedsagelig gjort sin forskning i arbejdsplads-kontekster, hvor hun har undersøgt informationspraksis, ved at afdække hvilke kontekster nyansatte skal være i stand til at trække information ud af, i deres proces med at blive "fuldgyldige" medlemmer af praksisfælleskabet (Lloyd, 2006; Lloyd, 2007a; Lloyd, 2005; Lloyd, 2007b; Lloyd, 2009).

Lloyd mener, at informationskompetence-begrebet dækker over den enkeltes evne til at kunne danne sig et overblik over informationsressourcerne i en given kontekst. Hun beskriver denne proces som "at læse et 
informationslandskab" (Lloyd, 2010b, s. 9). I denne proces mener Lloyd, at det sociale/sociokulturelle har afgørende indflydelse på den måde, der indhentes og deles information (Lloyd, 2007b; Lloyd, 2010a).

Med fokus på det sociale udfordrer Lloyd altså den gængse opfattelse af informationskompetence, som har fokus på formelle tekstbaserede kilder. Ifølge hende kan de tekstbaserede informationskilder ikke give den "tavse" viden (Lloyd, 2009, s. 403), som udgøres af erfaringsbaseret praksisviden.

På baggrund af sine kvalitative undersøgelser skitserer Lloyd, tre typer af information, som bidrager til udvikling af fagprofessionalitet, og som udgør "informationslandskabet" i en given kontekst (Lloyd, 2007a; Lloyd, 2009): Information som en tekstbaseret oplevelse; Information som en social oplevelse; og Information som en kropslig oplevelse.

Information som en tekstbaseret oplevelse: Lloyd definerer tekstuel information, som eksplicit og sanktioneret information, som sætter individet $\mathrm{i}$ stand til at udvikle processuel viden. Den tekstbaserede information udgør fundamentet for læring af en fremtidig praksis, idet den operationaliserer institutionel sanktioneret praksis gennem eksempelvis lærebøger, retningslinier og manualer. Tekstuelle informationskilder udgør, ifølge Lloyd kernen i en uddannelsesmæssig informationsoplevelse (Lloyd, 2009, s. 403).

Information som en social oplevelse: Ved at indgå i en social kontekst lærer praktikere at bruge andre praktikere, som kilder til erfaringsbaseret viden (ibid, s. 417). Social information skaber, ifølge Lloyd, identitet og tilhørsforhold, gennem viden om hvad fællesskabet værdsætter. Udveksling af information gennem anekdoter og beretninger udgør, ifølge Lloyd, en vigtig kilde til at informere egen praksis, og til at skabe en faglig stolthed (ibid, s. 407). Ved at "tappe" viden fra andre kan man udfylde huller i egen viden, og samtidig bruge andres tolkninger til at be- eller afkræfte egne antagelser. I interaktion med praksisfællesskabets medlemmer udvikles over tid en fælles meningsforståelse og praksisidentitet (Lloyd, 2007a, s. 190).

Hos Lloyd er evnen til at bruge praksisfællesskabets medlemmer som informationskilder afgørende for, at novicen kan erhverve sig en professionel identitet.
Erfarne medlemmer er autoriteter i praksisfællesskabet, hvor novicen kan få adgang til den erfarnes tavse og erfaringsbaserede viden (Lloyd, Williamson 2008). Den "tavse" viden kan ikke udtrykkes direkte eller eksplicit, men er det der siges "mellem linierne", for eksempel holdninger eller handlemåder.

Information som en kropslig oplevelse:

Lloyd betoner øvelse og observation, som handlinger der bringer kroppen ind i læringen, således at der kan udvikles en kropslig kompetence. Observation af andres praksisudførelse udgør en central kilde til "tavs" viden, om måder hvorpå praksisfællesskabet udfører opgaver. Her er tale om information som alene kan hentes i situationer - ved at være bundet til opgaveudførelsen (Lloyd, 2009, s. 415).

Praksiserfaring kan give en rutine som "sidder i kroppen" (ibid, s. 402). Kropslig viden kan eksempelvis være en mavefornemmelse for en passende handling i den konkrete situation, og deling af kropslig viden kan rent praktisk finde sted gennem observation af erfarne praktikere.

Erfarne praktikeres beretninger og situationsbundne viden sætter novicen i stand til at kortlægge mennesker som informationsressourcer.

\section{Arbejdsplads-versus Uddannelseskontekst}

Der er et åbenlyst paradoks i at anvende Lloyds teori, som er formuleret på baggrund af et studie af bl.a. brandmænd, på en uddannelseskontekst. Lloyd siger selv, at mulighederne for adgang til praktisk viden gennem sociale og kropslige informationskilder er begrænsede i den formelle uddannelseskontekst, på grund af uddannelsens dekontekstualiserede natur (ibid, s. 403). Begrebet "dekontekstualieret" har hun fra Jean Lave, som netop problematiserer uddannelsessystemets isolerede natur fra det virkelige arbejdsliv. I uddannelsessystemet bliver læring til en "vare" som skal "sælges" til eksamen; man lærer i stor udstrækning for at kunne udtrykke viden i forbindelse med bedømmelse (Lave \& Wenger, 2007, s. 95). Læringens varegørelse i uddannelseskonteksten er, ifølge Lave, med til at skabe afstand mellem uddannelsen og de reelle læringsbehov i det kommende arbejdsliv. Undervisningens indhold kan opleves at have mindre grad af mening, derved at den har en instrumentel funktion, altså blot er et middel til at bestå eksamen. 
Lloyd beskriver uddannelseskonteksten som et kontrolleret miljø, der ikke kan redegøre for realiteter, usikkerheder og for den række af informationskilder, som er nødvendige i den virkelige arbejdsudførelse. I udførelse af det praktiske arbejde skal mennesker få den tekstbaserede information til at stemme overens med den kropslige og sociale information, som opleves i den praktiske udførelse af arbejdet (Lloyd, 2009, s. 404).

Lloyds teori er selvsagt anvendelig i en praktisk arbejdsplads-kontekst, og forventelig ikke direkte overførbar til en akademisk kontekst, hvor arbejdsudførelsen i højere grad er af kognitiv karakter. Når vi vælger at anvende Lloyds teori i forhold til uddannelseskonteksten, er det for at undersøge, hvor langt hendes teori dækker indenfor uddannelseskonteksten.

Vi mener ikke, at Lloyds tre informationskilder tegner et dækkende billede af informationspraksis i en uddannelseskontekst og inddrager derfor begreber fra det individorienterede konstruktivistiske læringsperspektiv. Således sammenstiller vi det sociokulturelle og det individuelle i antagelsen om, at såvel det ydre som det indre påvirker studerendes informationspraksis.

Vi mener at begreberne "alignment" (Biggs, 2003) og "satisficing"(Simon \& Barnard, 1965) kan være med til at belyse uddannelseskontekstens vilkår, og dermed studerendes valg af informationskilder, ved at være baggrundsfaktorer som influerer informationspraksis. Det er klart, at vi hermed tilfører analysen to begreber, som ikke nødvendigvis har samme videnskabsteoretiske baggrund som den socialkonstruktivistiske teori Lloyd arbejder ud fra, og at vi på den måde kan komme til at ændre i betydningen af begrebet 'informationspraksis'. Vi vurderer dog, at vi hermed får opstillet et begrebsapparat, der skaber en, $i$ forhold til vores empiriske materiale, relevant problemstilling.

"Alignment" og "satisfycing"

"Alignment" er blevet et populært begreb indenfor uddannelsessektoren, fordi det forholder sig til de udfordringer, som uddannelsessystemet står i. Mange studerende er svære at motivere, og det stiller krav til læringsfokuserede aktiviteter. Når der er sammenhæng imellem, hvad man ønsker at nå (læringsmål), måden man underviser på, og måden hvorpå man bedømmer studerendes præstationer (eksamen), er un- dervisningen langt mere effektiv, end når dette ikke er tilfældet (Biggs, 2003).

Denne effektive undervisningstilrettelæggelse kaldes "alignment". Begrebet kan således bruges til at analysere en uddannelsesmæssig kontekst, i forhold til graden af sammenhæng (alignment) mellem ovenstående. Uddannelsens læringsmål, undervisning og bedømmelsesformer, siger noget om konteksten, fordi de er med til at påvirke den lærendes adfærd og motivation (Biggs, 2003). Det er af afgørende betydning for de studerendes læring, at undervisningen dertil forsøger at fremme dybdelæring, fremfor overfladelæring. Nogle af de ting der kan føre til overfladelæring hos studerende, er deres oplevelse af: "bare at skulle bestå"; for lidt tid; for stor arbejdsbyrde; misforståelse af krav og manglende evne til at forstå stoffet (ibid, s. 15).

John Biggs beskriver motivation som et springende punkt for læring, hvor "alignment" skaber en rød tråd gennem et undervisningsforløb, som giver mening for de studerende (ibid, s. 53). Denne overensstemmelse skaber en gennemsigtighed gennem undervisningsforløbet, fordi de krav der stilles i forbindelse med eksamen, har været eksplicitte i læringsmål og undervisning.

Vi har brugt Biggs teori om "alignment" til at forklare, hvordan studerendes oplevelse af mangel på samme, indvirker på deres informationspraksis.

Alignment relaterer sig til individers opfattelse af uddannelseskonteksten, som vi mener kan influere på studerendes informationspraksis.

"Satisficing" er en sammentrækning af "satisfy" og "sufficient". Begrebet stammer fra Herbert Simon (Simon \& Barnard, 1965), der fremlagde det synspunkt, at mennesker i højere grad "tilfredsstiller" end "maksimerer", som på det tidspunkt var den dominerende administrative teori med hensyn til beslutningstagning (Brown, 2004, s. 1241).

Begrebet bruges indenfor biblioteks- og informationsvidenskaben til at forklare informationssøgningsadfærd, hvor mennesker laver en "tilstrækkelig beslutning" i forhold til at møde deres informationsbehov, uden nødvendigvis at overveje alle muligheder (Case, 2007). "Satisficing" er en mulig forklaring på det fænomen som Zipf i 1949 navngav "the Principle of Least Effort", at mennesker estimerer mæng- 
den af arbejde forbundet med en given opgave, nu og i fremtiden, og udfører den del af arbejdet nu, som de vurderer bedst vil reducere deres samlede indsats (ifølge Poole (1985) refereret i Fisher, Erdelez \& McKechnie, 2005, s.6).

Begrebet "satisficing" beskriver en "kognitiv økonomi", der styrer, hvornår der er anvendt tilstrækkelige ressourcer på en opgave. "Satisficing" er i princippet udtryk for rationalitet. Således finder Warwick at studerendes motivation og beslutningstagning kan forklares med "satisficing" deri, at deres motivation er drevet af opgavekrav, og deres informationssøgning bliver gennemført med minimal indsats (Warwick et al., 2009, s. 2412). Warwick konkluderer, at studerende vælger informationsressourcer og søgestrategier der ligger indenfor deres "comfort zone", på den måde, at de vælger metoder de allerede kender. Warwick et.al. finder at strategisk "satisficing" er forbundet med mangel på motivation, og prioritering af tiden på andre opgaver, end dem der er direkte relaterede til informationssøgning.

Vi bruger Simons teori om "satisficing" til at forklare, hvorledes de studerendes oplevelser af betingelser og vilkår, har betydning for de studerendes adfærd. "Satisficing" siger således ikke noget direkte om konteksten, men som grundlæggende drivkraft i menneskelig beslutningstagning kan begrebet forklare, hvorfor individer er tilbøjelige til at levere det tilstrækkelige fremfor det ypperste.

Hermed har vi præsenteret vores teoretiske grundlag, og i det følgende vil vores metoder og empiriske undersøgelse blive beskrevet.

\section{Materiale og metode}

I denne artikel præsenterer vi de væsentligste resultater fra vores afhandling (Schneider \& Thrige, 2011). Den fulde dokumentationen fremgår af vores afhandling. Ved citater angives uddannelse og nummerering af interviewperson, med henblik på identificering, eksempelvis ASB1 og SiA1.

Vores interviewpersoner er studerende på uddannelserne "Bachelor of Marketing and Management Communication (BaMMC)", Handelshøjskolen i Århus (ASB) og "Professionsbachelor i Sygepleje", Sygeplejerskeuddannelsen i Århus (SiA).
Vi har undersøgt otte studerendes oplevelse af akademisk opgaveskrivning og informationssøgning, dvs fire studerende fra hver af de to bacheloruddannelser (fire fra hver uddannelse). Vi har taget udgangspunkt i to uddannelseskontekster, for at åbne op for forskellige perspektiver på informationspraksis.

Interviewpersonerne er udvalgt blandt studerende på 5. semester. Disse har arbejdet med akademisk opgaveskrivning og litteratursøgning minimum to gange på deres bacheloruddannelse, og man må derfor antage, at de har erfaringer som gør, at de kan forholde sig til arbejdet med en akademisk opgave.

Vores undersøgelse er en beskrivende analyse af otte studerendes udsagn, og kan derfor kun være et udtryk for disse studerendes oplevelser. Jævnfør selvselektions-problematikken (Kerlinger \& Lee, 1999, s. 560-1) er der en sandsynlighed for, at disse studerende har ladet sig rekruttere til denne undersøgelse, fordi de føler trang til, og har særlige forudsætninger for, at udtrykke sig om arbejdet med en akademisk opgave. Dette kan have haft en effekt på vores resultater, og kræver derfor opmærksomhed i forhold til generalisering af resultaterne. En undersøgelse med studerende med mere varierende fagligt niveau, kunne have nuanceret vores undersøgelsesresultater.

Ud fra vores undersøgelse mener vi, at have tilstrækkeligt grundlag for at beskrive tendenser i studerendes arbejde med tekstuel, social og kropslig information. Vores interviewpersoner dækker studerende fra to forskellige institutioner og uddannelser, med de variationer dette kan afstedkomme omkring akademisk opgaveskrivning. På samme vis er der en mindre, men tilstedeværende, repræsentation af fagligt svagere studerende, som har bidraget til at nuancere vores resultater.

\section{Resultater}

I vores masterafhandling lavede vi en todelt analyse, af henholdsvis de studerendes studiepraksis, hvor vi søgte svar på hvorledes studerende oplevede arbejdet med akademiske opgaver og informationssøgning, samt deres oplevelse af undervisere/vejledere og medstuderendes roller, i deres arbejde med opgaver og informationssøgning. I vores anden delanalyse søgte vi svar på, hvilken betydning studerende tillagde tekstuelle, sociale og kropslig informationskilder i deres informationspraksis omkring den akademiske 
opgave, samt hvilken betydning deres oplevelse af "alignment" og "satisficing" havde på deres informationspraksis.

I denne artikel fremlægges vores undersøgelsesresultater fra de to delanalyser samlet.

\section{Tekstuelle informationskilder}

Brug af tekstuelle informationskilder er obligatorisk såvel som underforstået i en akademisk praksis.

De studerende skal læse en mængde defineret pensumlitteratur, og forventes at inddrage denne, og anden forskningsbaseret viden, i deres akademiske opgaver.

I vores undersøgelse har vi været interesserede $\mathrm{i}$ at undersøge, hvilke tekstuelle informationskilder studerende anvender i deres informationspraksis, og om der er forskellig brug heraf på de to uddannelser.

Vores analyse indikerer, at studerende på de to uddannelser foretrækker forskellige materialetyper til arbejdet med deres opgaver. Således henviser sygeplejestuderende (SiA) til brug af både bøger og artikler, men giver udtryk for oplevelser af barrierer i forhold til at bruge engelsksprogede tekster. Vi finder, at ASB studerende, som i dette tilfælde læser på en engelsksproget uddannelse, er mere indstillede på at afsøge internationale artikeldatabaser i forbindelse med deres opgaver. Alle studerende udtrykker usikkerhed i forhold til at relevansvurdere kilder/fund i forbindelse med søgning i referencedatabaser.

På SiA henviser to studerende til brug af specifik metodelitteratur, som støtte i skriveprocessen. På ASB skal opgaverne ikke indeholde et metodeafsnit, hvilket kan forklare, at studerende herfra ikke giver udtryk for at støtte sig til metodelitteratur i skriveprocessen.

De studerende på SiA skal følge specifikke opgavekriterier. Disse kriterier opleves som checklister i forhold til formelle indholdskrav til opgaverne, og de studerende støtter sig derfor meget til disse. På ASB efterlyses denne støtte:

"Jeg tror der er tvivl hver gang jeg skal i gang, hvad det egentlig er der skal med ... hvis man nu vidste, at hver opgave skal stilles op på den her måde, så skulle man overhovedet ikke tænke på det" (ASB2).

En anden ASB studerende oplever kun behov for at undersøge "regelsættet", hvis vejlederen ikke i tilstrækkelig grad formår at afklare forventningerne til opgaven (ASB4)

Vi finder, at studerende på begge uddannelser benytter sig af andres skriftlige akademiske produkter/opgaver, som inspiration i forbindelse med fastlæggelse af egen opgavestruktur, samt litteraturvalg.

\section{Sociale informationskilder}

Vores undersøgelse påpeger, at sociale informationskilder er afgørende for studerendes informationspraksis. De studerende skal kunne identificere/ kortlægge ressourcepersoner indenfor de sociale kategorier i informationslandskabet.

Faktorer som magt og autoritet har indflydelse på individets tilbøjelighed til at anvende social information i en given informationspraksis. Alle deltagere kan bidrage med social information, men på grund af deltagernes forskellige placering i praksisfællesskabet, vil informationen, som hver deltager bidrager med, valideres forskelligt.

Undervisere og vejledere, samt bibliotekarer, opfattes som autoriteter som kan afgøre, hvad der er gyldig og ikke gyldig informationspraksis i konteksten af den specifikke opgave, med opgavevejlederen som den største autoritet.

"Det er den vejleder man skal op til ved eksamen.

Det er dem der skal læse opgaven, så man skal gøre det på den måde de vil have det” (SiA2).

Formelle tekstuelle opgavekrav opleves at kunne gradbøjes og tolkes forskelligt, og det er derfor af afgørende betydning, at de studerende formår at afdække vejlederens præferencer herfor.

Undervisers feedback på præstationer, mundtligt såvel som skriftligt, opleves som en meget anvendelig social informationskilde, $i$ arbejdet med den akademiske opgave og informationssøgning. Studerende tager gamle opgaver frem i arbejdet med de nye, og oplever at brug af tidligere feedback er medvirkende årsag til gode/bedre bedømmelser. 
På begge uddannelsesinstitutioner er det praksis at underviserne henviser til pensum. De studerende giver udtryk for at opfatte pensum som validerede kilder, og anvender de "erfarne praktikeres", her undervisernes, tavse viden i deres egen informationspraksis.

Underviserne opleves som gode informationskilder i forhold til litteratur eller valg af referencedatabaser, men ikke som brugbare informationskilder i forhold til informationssøgning:

"Jeg synes ikke at de kommer med geniale råd ... de forventer at man finder et eller andet godt ... forventer at man ved hvordan man skal finde det $\mathrm{i}$ forvejen" (ASB2).

De studerende oplever, at underviserne har forventninger til deres informationskompetence, men at underviserne ikke selv er ressourcepersoner i forhold til informationssøgning.

Studerende på uddannelsen, det være sig i studiegruppen, i klassen, på årgangen, eller ældre årgange, udgør centrale sociale informationskilder i de studerende informationspraksis. Studerende forfiner deres evne til at kunne bedømme, hvordan andre studerende kan bidrage, eller ikke bidrage, med information, i takt med deres inddragelse i praksisfællesskabet omkring akademisk opgaveskrivning:

"Vi bruger ligesom hinanden, og vi har også en ide om hvad vi hver især er gode til... og ved ligesom hvor vi kan bruge hinanden. Så vi prøver ligesom at udnytte hinandens ressourcer" (SiA1).

Medstuderende kan man vende tingene med, her kan der sparres, og man kan teste sin egen forståelse op imod andres - eksempelvis omkring krav til opgaver (ASB3). Men ikke alle medstuderende opleves at kunne bidrage med brugbar information (SiA2).

I forbindelse med informationssøgning oplever nogle studerende at gruppemedlemmerne kan supplere hinanden i processen, andre oplever ikke at medstuderende har brugbar viden på området.

"En fra gruppen har prøvet sig frem, og så har vi fulgt med og set om vi kunne komme med gode ideer til ord at søge på"(SiA3) og "de andre studerende har heller ikke sådan $100 \%$ styr på det, så det er... meget ensartet hvor meget viden man har egentligt om det" (SiA2).

På SiA udarbejdes opgaverne i større studiegrupper, hvor man på ASB i større grad skriver alene eller i mindre grupper. Undersøgelsen viser, at studiegruppen udgør et praksisfællesskab i det større praksisfællesskab. Her udnytter man hinandens kompetencer på godt og ondt. Den store fælles videnbase mindsker behovet for at trække på medstuderende udenfor studiegruppen, men til gengæld betyder det også, at der i ringe grad trækkes på mere erfarne studerende.

Læringsmæssigt viser det sig at studiegruppen kan være et tveægget sværd. På den ene side kan de studerende i gruppen lære meget af hinanden, på den anden side udnyttes studiegruppen til en rationel opgavefordeling, som betyder at gruppedeltagere risikerer ikke at tilegne sig de påtænkte kompetencer i forbindelse med opgaveskrivningen, og dermed ikke blive i stand til at udfærdige akademiske opgaver på selvstændig vis.

Studerende på ASB taler i højere grad om at inddrage studerende udenfor gruppen. De arbejder i mindre grupper, og kan dermed have større behov for input fra andre i praksisfællesskabet. Dog forekommer der i samme grad en vurdering af en medstuderendes bidrag, og der er opmærksomhed på, at ikke alle medstuderende har en viden, som er detaljeret nok til at den kan anvendes.

\section{Kropslige informationskilder}

I vores undersøgelse var det vanskeligt at finde klare tilkendegivelser af interviewpersonernes brug af kropslig information. Dette kan skyldes at de studerende ikke har mange muligheder for at observere erfarne praktikere, så som undervisere og vejledere, $\mathrm{i}$ deres egen praksis omkring den akademiske opgave. De kan observere vejleder, hvis vedkommende hjælper den studerende ved at demonstrere en metode, men dette vil kun forekomme i et begrænset omfang $i$ et opgaveskrivningsforløb. Opgaveskrivning er overvejende en mental aktivitet, og er derfor vanskelig at gøre til genstand for observation.

Dog vil vi her trække enkelte eksempler på kropslig information frem, for at illustrere fænomenet. I forbindelse med en vejledning hos en bibliotekar beskriver en studerende hvad hun har observeret: 
"...de [bibliotekarerne] er meget gode til, "hvis du nu sætter det her i et citationstegn, eller skriver et OG, eller et spørgsmålstegn”, det kan virkelig have stor betydning for, hvad man ender med at få” (ASB1).

Her fungerer bibliotekaren som en erfaren praktiker, der kan demonstrere søgeteknik i praksis, og hendes handlinger bliver derfor kilde til kropslig information.

Flere studerende giver udtryk for at arbejde sig ind på emnet, ved hjælp af "mind mapping":

"Vi har brugt tavlen i grupperum, skrevet stikord, nøgleord, begreber - sat streger/pile" (SiA3).

Gennem observation og gentagen øvelse af metoden, bliver handlingen kropslig. Handlinger bliver kropslige, når de til en vis grad bliver "automatiseret".

Opsummerende, i forhold til brugen af tekstuel, social og kropslig information på henholdsvis SIA og ASB, har vi i vores undersøgelse fundet, at denne ligner hinanden på væsentlige punkter. De studerende har i høj grad brug for retningslinjer i forbindelse med opgaveskrivning, og de bruger meget energi på at afdække deres vejleders fortolkning af disse, da de ved, at denne fortolkning er afgørende i forbindelse med bedømmelse. Sociale informationskilder med autoritet har derfor en stor betydning i de studerendes informationspraksis. Medstuderendes input indgår også i dannelsen og nuanceringen af egen praksis, herunder ved hjælp af diskussion/forhandling om praksis. Kropslig information har været vanskelig at lokalisere i relation til akademisk opgaveskrivning, hvilket kan tilskrives vores metodevalg. Generelt mener vi at ASB og SIA studerendes beskrivelser af brugen af tekstuelle, sociale og kropslige informationskilder ligner hinanden, på tværs af fagligt tilhørsforhold og informationspraksis.

$\mathrm{Vi}$ anser det for en svaghed ved vores opstilling af Lloyds tre typer af informationskilder, at de ikke inddrager deltagernes opfattelse af de kontekstuelle faktorer, og deres indre motiver. Derfor vil vi, med det tidligere nævnte forbehold, redegøre i det nedenstående for de studerendes oplevelse af kontekstuelle faktorer, med udgangspunkt i begrebet alignment, og på individernes motivation med udgangspunkt $\mathrm{i}$ begrebet satisfycing.

\section{Alignment}

På begge uddannelser kommer de studerende med udsagn, som vi fortolker som oplevelsen af manglende alignment, f.eks. i forbindelse med deres omtale af kravene omkring brug af metode (ASB), informationssøgning og brug af litteratur (SiA). De studerende oplever således at tekstuel viden, så som regler og opgavekriterier, ikke er klare og nuancerede nok.

Vi fortolker det som udtryk for "alignment" problemer, når de studerende beretter om, hvordan vejledere internt på institutionen gengiver uddannelses- og opgavekravene forskelligt. Således oplever en studerende på ASB det forvirrende, at vejlederne lægger forskellig vægt på opgavernes metodedel (ASB4). En studerende oplever, at det er vanskeligt at finde information om kravene til brug af metode (ASB4). En anden efterlyser et eksplicit krav om metodeafsnit i opgaven (ASB2); hun mener at et sådant formelt indholdskrav kunne afhjælpe vanskeligheder med at samstemme metode- og teorivalg. Begge oplever metodeundervisningen som utilstrækkelig og flertydig (ASB4, ASB2).

Utilstrækkelig undervisning og vanskeligheder med at indhente tilstrækkelig formel (tekstuel) information om brug af metode, er faktorer, som vi mener, påvirker de studerendes informationspraksis i retning af at bruge sociale informationskilder.

Tre interviewpersoner på SiA (SiA2;3;4) oplever, at vejledere og undervisere har store forventninger til deres informationssøgningsfærdigheder, og til at disse skal afspejles i opgaverne, men finder ikke disse forventninger eksplicit udtrykt i opgavekriterierne til de akademiske opgaver på 3.-5. semester. På studiets 1 . og 2. semester er der krav om redegørelse for litteratursøgning i opgaverne, og også i bachelorprojektet.

Kravene til opgaverne, i starten og slutningen af uddannelsen, har påvirket underviserne og vejledere til at stille forventninger til studieopgaverne generelt, men dette er problematisk for studerende midt i uddannelsen, som ikke formelt er underlagt kravet om redegørelse for litteratursøgning. Her er altså ikke sammenhæng mellem formelle/tekstuelle og uformelle/sociale forventninger fra praksisfællesskabet. Eksemplet illustrerer, at det, i den akademiske såvel som i den praktiske kontekst, bliver afgørende, at kunne aflæse den tavse viden omkring den passende 
praksis for informationssøgning i praksisfællesskabet, for at blive accepteret af de erfarne praktikere.

Med udgangspunkt i Lloyds begreb om informationspraksis kan vi vise, at de sociale informationskilder spiller en stor rolle i uddannelseskonteksten, også større end Lloyd selv lægger op til. Med udvidelsen af begrebsapparatet med begrebet "alignment" ser vi, at de studerendes oplevelse af manglende sammenhæng strukturelt set synes afgørende for brugen af andre informationskilder end de tekstbaserede i de studerendes informationspraksis.

\section{Satisficing}

En indre mekanisme i form af "satisficing" påvirker individers adfærd uanset sociokulturelle forhold, hvorfor det ikke er overraskende, at vi ser studerende udøve "satisficing" i deres informationspraksis. På begge uddannelser fremhæver autoriteterne informationssøgning og brug af forskningsbaseret litteratur, alligevel praktiseres "satisficing" ved at:

"lave en knap så grundig søgning... og så bare finde nogle artikler, som man fornemmer, har et passende perspektiv. Det er min egen logik der siger mig at man behøver ikke lægge $100 \%$ i løbet af skoleåret" (ASB3).

En anden studerende undgår databasesøgning, ved i stedet at benytte sig af vejleders litteraturanbefalinger (ASB2).

På SiA kan rammerne, med krav om $20 \%$ selvvalgt litteratur i opgaven, være en forklaring på, at der primært anvendes pensum i opgaverne, og at kompleks informationssøgning nedprioritres, til fordel for bibliotek.dk søgninger. Der er ikke incitament til at overskride de $20 \%$.

Vi ser, at studiegrupper foretager arbejdsdeling af opgavens enkeltdele:

"I den ene studiegruppe havde jeg jo en der var forholdsvis god til at søge; så hun fik da bare lov til det. Så var der andre opgaver jeg var bedre til. Der har det været sådan lidt rollefordeling i grupperne" (SiA3).

Prioriteringen letter arbejdet med den akademiske opgave, men kan have den konsekvens, at studerende risikerer at gennemføre uddannelsen uden at tilegne sig de tiltænkte kompetencer.

Magtforholdet mellem studerende og opgavevejleder tilskynder studerende, til at prioritere deres indsats $\mathrm{i}$ relation til opgaven, i forhold til vejleders præferencer. Vi ser at vejleder har endog meget stor indflydelse på opgaveprocessen:

"Hvis hun gerne vil have noget meget udpenslet, jamen så må vi gøre det... det er jo sådan nogle småting hvor man pleaser lidt" (SiA4).

Her genkender vi Lave's argument omkring varegørelsen af viden (Lave \& Wenger, 2007), ved at vejleder, som skal bedømme opgaven, får styrende betydning; om vejleders disposition er rigtig eller forkert bliver af mindre betydning for den studerende.

Brugen af tekstuelle informationskilder kan påvirkes af satisficing adfærd, ved fravalg på baggrund af vejleders farvede budskaber:

"De siger, at "Den gode opgave" er fin at bruge, men det er ikke nødvendigt" (SiA2).

En anden underviser ville måske have præferencer for metodebogen, og med sine formuleringer have tilskyndet studerende til at sætte sig ind i "Den gode opgave".

På begge uddannelser giver studerende udtryk for, at uddannelsernes fokus på det akademiske kan opleves som uhensigtsmæssig, i forhold til efterfølgende erhvervspraksis:

"En universitetsuddannelse kan være lidt for fokuseret på det akademiske, og især når det er en business school... man kommer jo ud i erhvervslivet... så nogle gange tænker jeg at det her sted er det eneste sted vi skal bruge det, så måske vi skulle fokusere på noget andet?” (ASB2) .

Studerende oplever i et vist omfang, at deres bestræbelser på at opfylde uddannelsernes akademiske krav, er skønne spildte kræfter (SiA3). Vi antager at ovenstående oplevelser kan føre til en "satisficing" adfærd, hvor studerende baserer deres indsats på en vurdering af det tilstrækkelige. 
Satisficing adfærd kan knyttes sammen med alignment problemer (uoverensstemmelser), ved at eksplicitte læringsmål/vurderingskriterier er nødvendige motivatorer for studerendes tilegnelse af stof/kompetencer. Således efterspørger en studerende formelle krav om metodeafsnit (ASB2), og om redegørelse for litteratursøgning (SiA4), med den begrundelse at det ville motivere til en større og mere målrettet indsats.

Studerende økonomiserer deres ressourcer i forhold undervisere/vejlederes forventninger. Når rammevilkårene giver rum til fortolkning af den nødvendige indsats, kan dette medvirke til "satisficing" adfærd. Med "alignment" og "satisficing" kan vi således underbygge, at sociale informationskilder har afgørende betydning blandt interviewpersonerne. Vores resultater udfordrer Lloyd, ved at vise at de tekstuelle informationskilder ikke er overlegne i uddannelseskonteksten.

Inden konklusionen vil vi kort diskutere den valgte metode for undersøgelsen.

\section{Diskussion af den valgte metode}

Vi observerede, at det faglige niveau blandt de valgte interviewpersoner lå fra middel til højt, og det er sandsynligt, at deres dygtighed kan have fungeret som en motiverende faktor for at deltage i interviewundersøgelsen. Dermed kan der være sket en skævvridning i vores undersøgelse, da studerende, der har det vanskeligt med den akademiske opgave, kan tænkes at have en anden informationspraksis. Vi burde have truffet særlige foranstaltninger, for at rekruttere studerende med vanskeligheder i forhold til skriftlige opgaver, f.eks. ved at kontakte studievejledere med kendskab til sådanne studerende.

Det må yderligere forventes, at det asymmetriske magtforhold mellem interviewer og interviewperson har haft indflydelse på udsagnene i de afholdte interviews, i kraft af interviewers status som bibliotekar på institutionerne (Kvale \& Brinkmann, 2009, s. 50).

Vi kunne med fordel have udvidet vores undersøgelse med observation af de studerendes reelle informationspraksis. Især den kropslige information kan være svær at afdække ved hjælp af interview, da der i nogen grad kan være tale om "tavs viden"(Lloyd 2010 b s. 4). Dette indebærer, at det kan være svært at spørge ind til, hvordan de studerende konkret af- læser og bruger kropslig information fra andre, fordi de studerende måske ikke er bevidste om deres egen brug af denne. Emnet er derfor et område for en fremtidig undersøgelse.

\section{Konklusion og perspektivering}

Vores undersøgelse illustrerer, at de studerendes oplevelse af kontekstuelle faktorer synes at være af afgørende betydning for deres informationspraksis. De forholder sig til uddannelsens krav til deres opgaver, de forholder sig til egne ambitioner læringsmæssigt og performancemæssigt, de forholder sig til det ventende arbejdsmarkeds forventninger, og forsøger at samstemme disse med vejleders eventuelle divergerende signaler.

Med udgangspunkt i Lloyds begreb om informationspraksis kan vi vise, at de sociale informationskilder spiller en stor rolle i uddannelseskonteksten, også større end Lloyd selv lægger op til. Med tilføjelsen af begreberne "alignment" og "satisficing" ser vi, at de studerendes oplevelse af manglende sammenhæng strukturelt set, såvel som deres vurdering af, hvad der er en tilstrækkelig indsats, synes at påvirke brugen af informationskilder i studerendes informationspraksis.

Ved at se på informationskompetence som en bredere informationspraksis, som ikke kun relaterer sig til tekstuelle kilder, får det den effekt, at vi som bibliotekarer i højere grad skal forholde os til den studerende i kontekst. Vi skal forholde os til, hvilken status informationssøgning har i underviserkollegiet, og i uddannelsernes studieordning og opgavekriterier. Bibliotekarer bør have indgående kendskab til ressourcepersoner i undervisningsmiljøerne. På samme måde kan studerende udgøre væsentlige kilder til information om, hvad der er væsentligt for dem $\mathrm{i}$ forhold til at opfylde uddannelsens krav, og hvordan biblioteket kan hjælpe. Samarbejde med undervisningsmiljøerne og studerende kan, f.eks. sammen med mindre kvalitative brugerundersøgelser ${ }^{2}$, give grundlag for en ny og innovativ viden om vores brugere. Kun herved kan vi skabe de bedste strukturelle vilkår for udvikling af informationskompetencer, som kan matche samfundets komplekse videns- og læringskrav (Gleerup, 2011). 


\section{Noter}

1. Annemaree Lloyd er seniorforsker i Informationsstudier ved School of Information Studies, Charles Sturt University, Australia og forsker indenfor områderne Informationskomptence og Informationspraksis i kontekst.

2. Eksempler på metoder til brugerundersøgelser www.brugerkaravanen. $\mathrm{dk}$

\section{Referencer}

Bawden, D \& Robinson, L (2002). Promoting literacy in a digital age: approaches to training for information literacy, Learned Publishing, vol. 15, no. 4, 297-301.

Biggs, JB (2003). Teaching for quality learning at university: what the student does, 2. ed. edn, Society for Research into Higher Education, Maidenhead.

Brown, R (2004). Consideration of the origin of Herbert Simon's theory of "satisficing" (1933-1947), Management Decision, vol. 42, no. 10, 1240-1256.

Bruce, C (1999). Workplace experiences of information literacy, International Journal of Information Management, vol. 19, no. 1, 33-47.

Bruce, C (1997). The seven faces of information literacy, Auslib Press, Adelaide.

Case, DO (2007). Looking for information: a survey of research on information seeking, needs, and behavior, 2. ed. edn, Elsevier, Amsterdam.

Fisher, KE, Erdelez, S \& McKechnie, L (2005). Theories of information behavior, Information Today, Inc., Medford, N.J.

Gleerup, J (2011). Videns- eller informationssøgning $i$ konkurrencestaten, Bidrag til "Imagine VIA Bibliotekerne 2020" edn, http://studienet.viauc.dk.

Head, A \& Eisenberg, M (2009). Finding context: What today's colledge students say about conducting research in the digital age, The Information School, University of Washington.
Kerlinger, FN \& Lee, HB (1999). Foundations of behavioral research, 4. ed. edn, Harcourt Publishers Ltd College Publishers, Forth Worth, Tex.

Kvale, S \& Brinkmann, S (2009). Interview: introduktion til et håndvark, 2. udgave edn, Hans Reitzel, Kbh.

Lave, J \& Wenger, E (2007). Situeret laering - og andre tekster, Hans Reitzel, Kbh.

Lloyd, A (2005). Information literacy: Different contexts, different concepts, different truths?, Journal of Librarianship and Information Science, vol. 37, no. 2, 82-88.

Lloyd, A (2006). Information literacy landscapes: an emerging picture, Journal of Documentation, vol. 62, no. $5,570-583$.

Lloyd, A (2007a). Learning to put out the red stuff: Becoming information literate through discursive practice, Library Quarterly, vol. 77, no. 2, 181-198.

Lloyd, A (2007b). Recasting information literacy as sociocultural practice: implications for library and information science researchers, Information Research-an International Electronic Journal, vol. 12, no. 4 , colis 34 .

Lloyd, A (2009). Informing practice: information experiences of ambulance officers in training and onroad practice, Journal of Documentation, vol. 65, no. 3, 396-419.

Lloyd, A (2010a). Framing information literacy as information practice: site ontology and practice theory, Journal of Documentation, vol. 66, no. 2, $245-258$

Lloyd, A (2010b). Information literacy landscapes: information literacy in education, workplace and everyday contexts, Chandos Pub., Oxford.

Lloyd, A \& Williamson, K (2008). Towards an understanding of information literacy in context - Implications or research, Journal of Librarianship and Information Science, vol. 40, no. 1, 3-12. 
Pilerot, O (2009). Högskolestudenters informationskompetens I: J. Hedman \& A. Lundh (red), Informationskompetenser: om lärande i informationspraktiker och informationssökning i lärandepraktiker, 1. udg. edn, Stockholm, Carlsson, 108-132.

Rouse, J (2007). Practice theory. In: Philosophy of anthropology and sociology, (Eds). S.P. Turner \& M.W. Risjord, Elsevier, Amsterdam, 639-681.

Savolainen, R (2007). Information behavior and information practice: Reviewing the "umbrella concepts" of information-seeking studies, Library Quarterly, vol. 77, no. 2, 109-132.

Schneider, MV \& Thrige, S (2011). Informationspraksis omkring den akademiske opgave, Det Informationsvidenskabelige Akademi.
Simon, HA \& Barnard, CI (1965). Administrative behavior: a study of decisionmaking processes in administrative organization, - 2. ed. with new introduction. edn, New York: The Free Press.

Sundin, O, Limberg, L \& Lundh, A (2008). Constructing librarians' information literacy expertise in the domain of nursing, Journal of Librarianship and Information Science, vol. 40, no. 1, 21-30.

Tuominen, K, Savolainen, R \& Talja, S (2005). Information literacy as a sociotechnical practice, $L i$ brary Quarterly, vol. 75, no. 3, 329-345.

Warwick, C, Rimmer, J, Blandford, A, Gow, J \& Buchanan, G (2009). Cognitive Economy and Satisficing in Information Seeking: A Longitudinal Study of Undergraduate Information Behavior, Journal of the American Society for Information Science and Technology, vol. 60, no. 12, 2402-2415. 